\title{
A new genus and new species of Hyphinoini (Hemiptera, Membracidae, Darninae) ${ }^{1}$
}

\author{
Albino M. Sakakibara ${ }^{2,3}$ \\ ${ }^{1}$ Contribution $n^{\circ} 1477$ of the Departamento de Zoologia, Universidade Federal do Paraná. \\ ${ }^{2}$ Departamento de Zoologia, Universidade Federal do Paraná. Caixa Postal 19020, 81531-980 Curitiba-PR, Brazil. \\ E-mail:sakaki@bsi.com.br \\ ${ }^{3} \mathrm{CNPq}$ fellowship.
}

\begin{abstract}
Resumo. Um novo gênero e novas espécies de Hyphinoini (Hemiptera, Membracidae, Darninae). Hanstruempelia gen. nov.: H. ceresina sp. nov. (espécie-tipo) (Colômbia, Rio Orteguaza) e H. bitumina sp. nov. (Brasil, Rondônia) são descritos e ilustrados.

Palavras-Chave. Darninae; descrições; Hemiptera; Hyphinoini; Membracidae; taxonomia.
\end{abstract}

Aвstract. Hanstruempelia gen. nov.: H. ceresina sp. nov. (type species) (Colombia, Rio Orteguaza) and H. bitumina sp. nov. (Brazil, Rondonia) are described and illustrated. The new genus is included in Hyphinoini.

KEYwords. Darninae; descriptions; Hemiptera; Hyphinoini; Membracidae; taxonomy.

Among the specimens of Darninae (Membracidae) belonging to the Zoologisches Institut und Zoologisches Museum der Universität Hamburg, Germany (ZMUH), sent for study by Dr. H. Strümpel, was a species very different from those already known. In the collection of the Departamento de Zoologia, Universidade Federal do Parana, Curitiba-PR, Brazil (DZUP), a congeneric new species was found. They are described herein as a new species in a new genus. Running the key (Deitz 1975; Dietrich, Mckamey \& Deitz 2001), they go to Hyphinoini Haupt, 1929, but some characters do not match with those of the key. The second species, in particular, does not present cucullate setae on the plantar surface of the first metatarsomere. They are considered, however, congeneric and belonging to Hyphinoini.

A small modification in the DeITz's (1975) key is proposed to allow the inclusion of this new genus in the tribe, as follows:

16'. Metathoracic tibia (.....) usually with three rows or bands of cucullate setae; abdomen usually with dorsal tuberosities or paired dorsal fenestrae (.....)

17

$17\left(16^{\prime}\right)$. First metathoracic tarsomere (.....) usually with 2-20 cucullate setae on plantar surface and with five or six cucullate setae apically; forewings entirely exposed or partially concealed by pronotum in repose; metathoracic leg with coxa and trochanter unarmed. HYPHINOINI

\section{Hanstruempelia gen. nov.}

Type species: Hanstruempelia ceresina sp. nov.

Head approximately twice wider than long; vertex smooth, weakly sculptured; superior margin distinctly arched between eyes. Eyes ovate and slightly prominent. Ocelli situated just below the imaginary line that passes through the center of eyes, slightly nearer to them than to each other. Suprantennal lobules not differentiated from the rest of the vertex, with margins straight. Posclypeus in the same plan of vertex, more or less ovate, almost as wide as long.

Pronotum strongly inflated above the head, inclined forwards; posterior process tectiform, shorter than tegmina, the contour line gradually descending to the pointed tip; lateral semicircular marking well impressed. In frontal view, greatly inflated upwards and laterally, more than three times the width of head; strongly impressed above humeral angles.

Tegmina entirely exposed, translucent and densely pilose; veins $\mathrm{R}, \mathrm{M}$, and $\mathrm{Cu}$ close together at the base; crossveins s, $\mathrm{r}$ $\mathrm{m}$, and two $\mathrm{m}$-cu present; external discoidal cell narrow and slightly longer than the inner one; five apical cells (extranumeral veinlets may occur in $\mathrm{R}$ branches).

Legs normal; pro- and mesothoracic legs without cucullate setae; metathoracic legs with coxa and trochanter unarmed; femur without longitudinal row of cucullate setae; first tarsomere with/without cucullate setae on plantar surface.

Abdomen without middorsal spots or fenestrae.

Comments. This new genus is considered as belonging to Hyphinoini Haupt, 1929. Some characters, however, do not match with those pointed out by Deitz (1975), such as: pronotum not attaining apex of tegmina; tegmina entirely free; metathoracic leg with or without cucullate setae on plantar surface.

In Hanstruempelia gen. nov. the head is relatively short, being about twice as wide as long; the pronotum is well developed above the head in an inflated turban-shape process; 

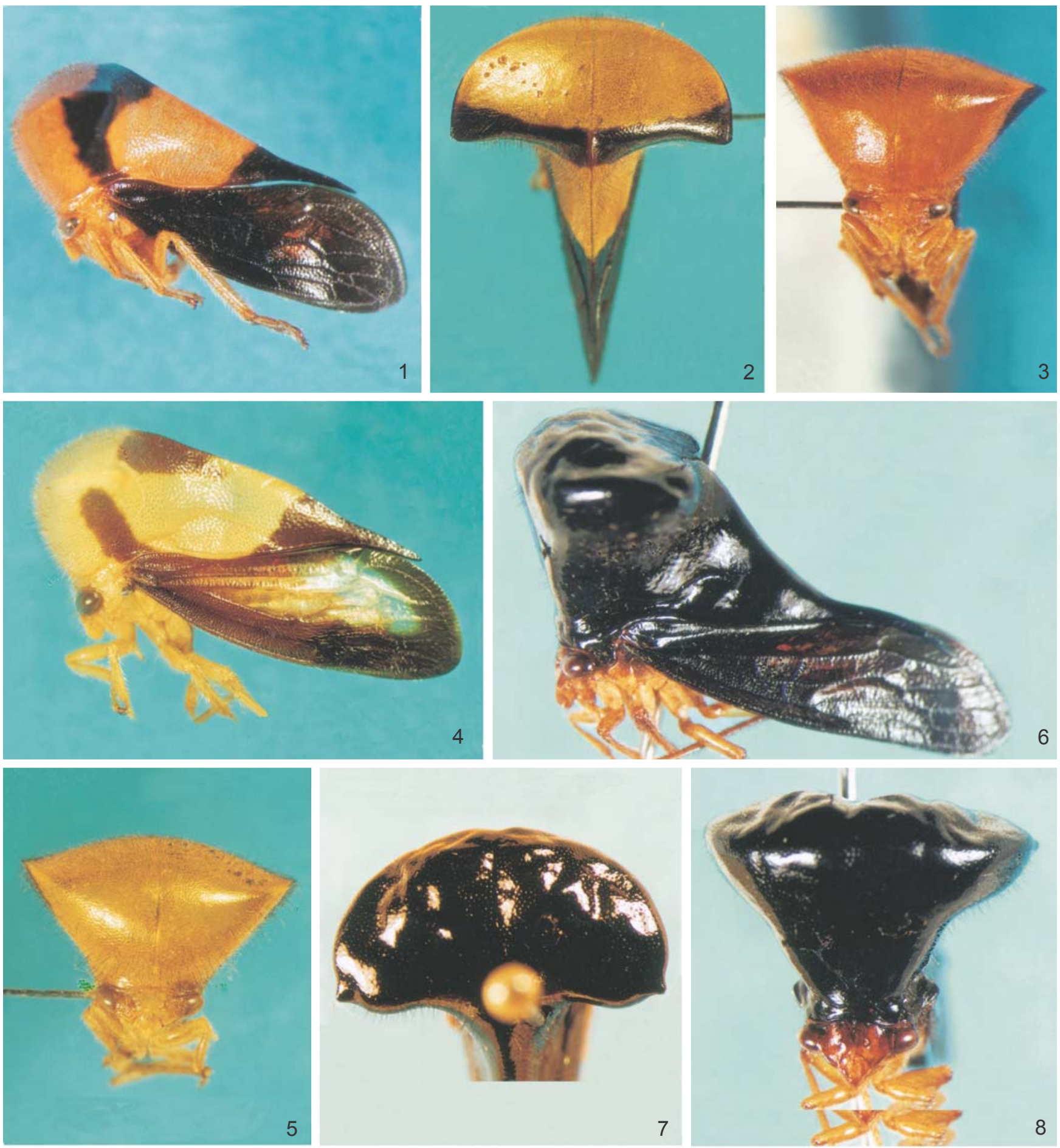

Figs. 1-8. Hanstruempelia gen. nov.: 1-3, H. ceresina sp. nov. (holotype male), lateral, dorsal and frontal views; 4-5, H. ceresina (female), lateral and frontal; 6-8, H. bitumina sp. nov. (holotype male), lateral, dorsal (partial), and frontal.

in front view, it is deeply constricted above the humeral angles, just like in Eualthe Stål, 1867; posterior process, on the other hand, is shorter than the tegmina, tapered distally, and terminating between the apex of clavus and apex of tegmina. The abdominal terga do not present fenestrae or tubercles.

The generic name is derived from Hans Strümpel, to whom the taxon is dedicated.

\section{Hanstruempelia ceresina sp. nov.}

(Fig. 1-5)

Holotype male. Head and pronotum orangish-yellow; a 
narrow stripe extending transversally from humerus to humerus, passing on top of anterior process, and apical third of posterior process, black. Tegmina entirely dark, translucent. Thorax, legs, and abdomen, yellowish, except genital segments black.

Head triangular, relatively small, narrower than distance between humeral angles, about twice as wide as long.

Pronotum inflated anteriorly, above head, in a balloon-like process; in frontal view, largely expanded upwards, with upper surface distinctly convex, and acutely angulate at each side; anterior process, in dorsal view, half-moon shaped, with convex side turned forwards, lateral angles acute provided with a faint antero-lateral carina evanescent and disappearing before reach metopidium. Posterior process tectiform, lateral semi-circular impression well marked, mid-longitudinal carina sharp, dorsal contour line gradually descending to slender, acute apex; process terminating just beyond apex of clavus.

Tegmina free, about 2.7 times longer than wide, darksmoked, densely covered with a fine and long hair-like setae.

Female. Very similar to male in overall appearance; coloration, instead of orangish, it goes to yellowish, and tegmina present an oblong discolored area at disc. The black stripe of anterior process is slightly widened at middle and interrupted on each side at lateral angles.

Measurements (in mm). Male/female. Total length, 10.6/ 10.8; length of pronotum, 8.8/9.2; height of pronotum (frontal view), 3.7/3.7; maximum width of pronotum (frontal view), 6.8/ 6.6; distance between humeral angles, 3.2/3.3; width of head, 2.7/2.9; length of head, 1.2/1.3.

Holotype male. COLOMBIA. "Columbien | Rio Orteguaza 10.8.1947” "Leg. L. Richter | 01617" "Z.M.H. | Hamburg” (ZMUH). Paratypes. 11 males and 2 females from the same locality as holotype, except following data: 3 males, 12.9.1947, 01604; 8 males, 10.8.1947, 01617; 1 female, 12.9.1947, 01604; 1 female, 11.9.1946, 01602. 7 males and 3 females from "Columbien, Caucaya|Putumayo | Nov. 1948" "Leg. L. Richter | 01608" "Z.M.H. | Hamburg", except following data: 1 male, November 1948, 01615; 3 males, Dezember 1948, 01614; 1 male, 01609; 1 male, Buena Vista | 25.12.1942 | 01613; 1 female, November 1948, 01615; 2 females, Dezember 1948, 01614. (ZMUH; 2 males and 1 female in DZUP).

Comments. This species differs morphologically from all others of the tribe. It could be compared with Hyphinoe asphaltina (Fairmaire, 1846) but, the new species is: smaller, with the pronotum greatly inflated, and distinctly constricted at each side above humeral angle; the posterior process is short, not attaining the apex of tegmina, and the abdomen lacks middorsal tubercles. The form of the posterior process is very similar with that of Ceresa Amyot \& Serville, 1843 - this similarity suggested the specific name.

\section{Hanstruempelia bitumina sp. nov.}

(Figs. 6-8)

Holotype male. Pronotum and tergmina entirely black, brilliant, pitch-like; head, thorax, legs, and abdomen castaneous.

Head triangular, relatively small, narrower than distance between humeral angles, about twice as wide as long.

Pronotum inflated anteriorly, above head, in a balloon-like process; in frontal view, largely expanded upwards, with upper surface somewhat convex, irregularly undulate, shallowly sulcate longitudinally along mid-dorsal carina; in dorsal view, half-moon shaped, laterally rounded, provided at each extreme with a small knob-like protuberance. Posterior process more or less tectiform, without mid-longitudinal carina, semi-circular impression well marked, posterior third abruptly slender, carinate dorsally, curved and parallel to internal margin of tegmina, and terminating about end of the vein M3-4.

Tegmina free, about 3.3 times longer than wide, darksmoked, densely covered with a fine hair-like setae.

Metathoracic legs with first tarsomere without cucullate setae on plantar surface, and four-five apically.

\section{Female. Unknown.}

Measurements (in mm). Male. Total length, 13.6; length of pronotum, 11.6; height of pronotum (frontal view), 5.6; maximum width of pronotum (frontal view), 8.4; distance between humeral angles, 3.7; width of head, 3.0; length of head, 1.5 .

Holotype male. "BRASIL: RO | Vilhena, 600m |10. xii. 1995 | A. Camargo col”. (DZUP).

Comments. This species is quite similar to the preceding one in the form of pronotum; the anterior process is more voluminous, laterally rounded, and provided with a small nipple-like protuberance at each tip.

The specific name alludes to the black and shining pronotum, like pitch (= bitumen).

\section{REFERENCES}

Deitz, L. L. 1975. Classification of the higher categories of the New World treehoppers (Homoptera:Membracidae). North Carolina Agricultural Experiment Station Technical Bulletin 225: 1177.

Dietrich, C. H.; S. H. McKamey \& L. L. Deitz. Morphology-based phylogeny of the treehopper family Membracidae (Hemiptera: Cicadomorpha: Membracoidea). Systematic Entomology 26: 213239. 